\title{
A post-foundational Practical Theology? The pastoral cycle and local theology 1
}

\begin{abstract}
The article argues that Practical Theology has moved from the uncertainty of simply being applied theology to a point where its methodology, here described as the pastoral cycle, has gained such confidence, that it is seen as the natural way of doing theology. This shift in confidence occurred because the inherent theological and epistemological fault lines in foundationalism are no longer obscure. The article defines foundationalism but then concentrate on describing the local and glocal dimensions of the pastoral cycle as well as the importance of doing it in an interdisciplinary way.
\end{abstract}

\section{INTRODUCTION}

Practical Theology has been in flux as a discipline for some time. What characterises the discipline at the present time? How has the discipline changed in the last few decades? This paper seeks to address this question from the standpoint of whether Practical Theology has moved beyond foundationalist assumptions. It will be argued that it has. This can be seen by the fact that it affirms the pastoral cycle in terms of its overarching method. It is at the same time starting from and moving to practice. The article will focus on the pastoral cycle, while at the same time looking at the local dimension of Practical Theology as part of its "first movement" within the pastoral cycle. Before exploring this we must give a brief definition and understanding of foundationalism.

\section{FOUNDATIONALISM²}

1 The article is based on Macallan's doctoral dissertation (2012). Hendriks was promoter \& Dr Ian Nell co-promoter.

2 Although foundationalism will be explored later it is important to bring clarity to how this term is distinguished from anti, non and post foundationalism, as scholars use the terms differently and interchangeably. It is also important to show the relationship between post-modernism and foundationalism. Anti-foundationalism (Baronov 2005:139-140) is the critique of foundationalist assumptions connected with modernism, that like some aspects of post-modernism, leans towards a relativistic outlook. Non-foundationalism (Thiel 1994:2) is also a critique of foundationalist modernist assumptions, yet is not relativistic as much as it is a statement of what is "not philosophically tenable". Post-foundationalism accepts many of the criticisms of anti and non-foundationalism, but seeks to move "creatively" forward to some form of resolution of these philosophical dilemma's (Van Huyssteen 1997:4). Post-modernism is not dissimilar to the various categories of foundationalism just mentioned. It can lean towards a relativisitic outlook or have more positive and constructive overtones. Foundationalism, with its history in the pragmatic philosophers of the late nineteenth and early $20^{\text {th }}$ centuries, predates post-modernism (Thiel 1994:6-7). They are however linked by their critique of modern enlightenment foundationalism and its quest for "unimpeachable foundations of knowledge" (Schrag 1992:23). 
In many ways, we are all foundationalists in our attempt to root our knowledge in something more basic, or on various other presuppositions. Grenz and Franke (2001:29) note:

In its broadest sense, foundationalism is merely the acknowledgment of the seemingly obvious observation that not all beliefs we hold (or assertions we formulate) are on the same level, but that some beliefs (or assertions) anchor others. Stated in the opposite manner, certain of our beliefs (or assertions) receive their support from other beliefs (or assertions) that are more "basic" or "foundational."

However, the foundationalist agenda goes further than this and hopes to ground our knowing on a basis that can provide us with certainty and deliver us from error. This basis is regarded as universal and context free and is available to any rational person (Grenz \& Franke 2001:30). This approach can be either deductive or inductive, from innate ideas or the sensory world. Rene Descartes is viewed by many as the "father" of foundationalism in his attempt to establish a sure foundation for knowledge in that he

[C]laimed to have established the foundations of knowledge by appeal to the mind's own experience of certainty. On this basis he began to construct anew the human knowledge edifice. Descartes was convinced that this epistemological program yields knowledge that is certain, culture-and tradition-free, universal, and reflective of a reality that exists outside the mind (this latter being a central feature of a position known as "metaphysical realism" or simply "realism") (Grenz \& Franke 2001:30).

Descartes is central to the story, not only because of his influence, but because non-foundational critics see his thought as paradigmatic of foundationalism (Thiel 1994:3). Descartes believed knowledge could be free from doubt and error with simple and known truths on which knowledge could be based (Kung 1978:7).

Others, like John Locke (1632-1704), argued that sense experience is the foundation of knowledge, which is also known as empiricism (Grenz \& Franke 2001:32). Hume (1711-1776), also part of the British empiricist tradition, "argued that sense experience and not ideas provides a grounding for philosophical inquiry" (Thiel 1994:5).

The Enlightenment foundationalist agenda has shaped both conservative and liberal approaches to theology. Grenz and Franke (2001:32-35) have shown that both sought to build their reflections on the assumptions of the foundations of either religious experience or an inerrant bible. This quest for certainty, regardless of foundations, had the impact of Practical Theology simply becoming an applied theology of the other theological disciplines. Sure foundations, sure knowledge, context free application. Has Practical Theology moved on from these forms of applied theology derived from the foundationalist modernistic project? It is our argument that its embrace of the pastoral cycle and its turn to the local context has indeed shifted it beyond foundationalism.

\section{THE PASTORAL CYCLE}

The pastoral cycle has taken on wide importance within Practical Theology. Ballard and Pritchard (2006:82-83) comment as follows:

"The pastoral cycle has become widely used in Practical Theology, and there are a number of variations on the theme .... Such widespread acceptance clearly suggests that 
the pastoral cycle should be at the heart of any contemporary perspective on Practical Theology."

The pastoral cycle has many roots but, in contemporary Practical Theology, it certainly has found its impetus from the influence of liberation theology (Ballard \& Pritchard 2006:82).

Graham et al. (2005) place the pastoral cycle's roots, developed by liberation theology, in the Young Christian Workers' "see-judge-act" method. It was also in the work of Juan-Luis Segundo's The liberation of theology (1976), informed by Paul Ricoeur's hermeneutics, that the pastoral cycle was popularized (2005:188).

We noted that Ballard and Pritchard feel that the pastoral cycle has a wide acceptance within Practical Theology. It is no wonder then that Don Browning (1991:7), who developed a critical correlational model, in fact adheres in many ways to this pastoral cycle. A quote from him perhaps best affords us a definition of what we mean by the pastoral cycle:

"The view I propose goes from practice to theory and back to practice. Or more accurately, it goes from present theory-laden practice to a retrieval of normative theory-laden practice to the creation of more critically held theory-laden practices."

This pastoral cycle is not dissimilar to the theological reflection that James and Evelyn Whitehead propose in their book, Method in ministry: Theological reflection and Christian ministry, published in 1995. They propose a three-step process similar to the see-judge-act, or the practice-theoryaction process for which the pastoral cycle argues. The process that they propose is one of attending, asserting, and then pastoral response (Whitehead \& Whitehead 1995:13). One attends to a specific experience or practice that is then brought into dialogue with the Christian tradition and culture where an assertion is made, which in turn leads to a pastoral response. Here, the term "pastoral concern," taken from the Whiteheads, has been used when discussing the first part of the pastoral cycle. The term "pastoral action," similar to the Whitehead's term "pastoral response," but borrowed from De Kock, has also been used. De Kock has developed a form of theological reflection in what is known as "open seminary." Here, he essentially works with, adapts, and actually fleshes out, the Whiteheads' methodology. He chooses to call the term "pastoral response" or rather "pastoral action." This is done intentionally to show that the pastoral cycle must not end in a theoretical proposal for action, but must go beyond that and move to an intervention, or action (de Kock 2011:9).

Poling's (2009:199) description of Practical Theology demonstrates this pastoral cycle whereby he advocates a "rhythm between practice-based reflection and systematic theological reflection. Practices stimulate theological reflection, and theological reflection shapes the development of practices".

So, what does it mean to begin one's theological reflection with a pastoral concern? It means that certain local and global factors ought to be taken into account. It also affirms the importance of experience as a source for theological reflection, as well as the value of social analysis or research. Some of these aspects will be discussed in this paper.

\section{THE LOCAL DIMENSION OF PRACTICAL THEOLOGY}

Essential to understanding the local nature of theology is to admit from the outset that an applied Practical Theology, a theology from above that is trans-historical and simply downloaded onto a local situation, is indeed a thing of the past, a foundationalist past. For, as Hendriks (2004:27) notes, "If Christianity really wants to engage the hearts and minds of believers, it must seriously 
regard the context that shapes their lives and in which their communities are rooted." By arguing for the starting point of theology in the local, we reject "theological debate which proceeds as if abstracted from the total situation in which reflection takes place" (Bonino 1975:86). By arguing for the local nature of theology, we agree with Segundo (1976:13) that there is no "autonomous, impartial, academic theology floating free above the realm of human options and biases." Theology does not begin in the academy, but in reality, - in the experiences of "individuals and communities" (Cochrane, de Gruchy \& Peterson (1991:17). It resists a form of abstract theology (Kretzschmar 1994:4)

This means that theological reflection must begin with the "stuff" of people's lives.

The word "praxis" is controversial. Bevans (2002:72) sees praxis as "action in reflection" and defines it in the following manner:

It is reflected-upon action and acted-upon reflection - both rolled into one. Practitioners of the praxis model believe that in this concept of praxis they have found a new and profound way that, more than all others, is able to deal adequately with the experience of the past (Scripture and tradition) and the experience of the present (human experience, culture, social location, and social change).

Bevans (2002:71) rejects an understanding of praxis that equates it simply with practice. He notes its roots in Marxism, the Frankfurt school and Paulo Freire. For Bevans, it is rather a method and model of thinking. It seems that others would agree (Hendriks 2004:22; W. de Kock 2011:9). De Kock views praxis as the interaction and tension between theory and practice where true knowledge lies. Kim (2007:421) has noted the roots of praxis in Aristotle's thinking, where theory and practice are intertwined, and where praxis referred to "a purposeful and reflective action initiated through engagement in social situations." Clodovis Boff (1987:213) also argues for a tension between theory and practice. In fact, he argues that even though they are to be differentiated, it is artificial when one tries to separate the two. Yet, it seems that despite Boff (1987:210) speaking of praxis as "human activity to transform the world" (which includes a theoretical dimension), he still uses praxis in a "practical sense" as the starting point for theological reflection. In the following quote, Boff (1987:215) argues for praxis as holding primacy as a starting point for theology:

It must first of all be acknowledged that praxis holds the primacy over theory. This primacy is of an analytical, not an ethical, character. It is not to be understood as one of mechanical causality, but precisely of dialectical causality. It defines how the one factor is the prime, material condition for the existence of the other. Praxis is de facto the comprehensive element of theory; as such it constitutes the space where theory is localized and defined, the space where it arises, develops, and comes to completion.

Although affirming the importance of the local for theological reflection, Boff cautions against equating the local situation as truth. This would perhaps again fall prey to foundationalist assumptions. Practical effectiveness, or a pragmatism that rejects theoretical reflection, is rejected. For Boff (1987:202), the local practice of something does not assign a "moral qualification" to it. He argues that taking local practice into account at the expense of theory is to the detriment of praxis itself (1987:198).

Here, we are perhaps getting ahead of ourselves. The point that is attempted is that the starting point of the pastoral cycle must begin with the practice of real life. It cannot start by taking abstract ideas and seek to work them out in local realities. A post-foundationalist approach 
to Practical Theology must emphasize these local realities, as knowledge is contextual and fluid. Muller (2009:5) describes it thus:

The postfoundationalist approach forces us to firstly listen to the stories of people in real life situations. It hasn't got the aim of merely describing a general context, but of confronting us with a specific and concrete situation. This approach, although also hermeneutical in nature, moves beyond mere hermeneutics. It is more reflexive and situationally embedded in epistemology and methodology.

Practical Theology must begin its dialectical process by listening to the "emerging questions" (de Kock 2011:8; Cronshaw 2011:6) that arise out of the daily cultural realities of human beings and the church. It takes seriously the current issues of the day (Chopp 1995:115). Praxis "prepares the agenda, the repertory of questions, that theology is to address" (Boff 1987:200).

We have realised that by arguing for the local nature of theology, we argue for a contextual theology, as against an applied theology based on foundationalist assumptions. Bevans (1992:9) points out the importance of contextual theology today. He notes the dissatisfaction and suspicion of the Third World toward First World Theology, which has overpowered them and forced them to deal with realities irrelevant to their daily lives. Along with the growing identity of local churches, the oppressive nature of the older approaches that neglected and, in fact, attacked legitimate cultural expressions, has also been rejected (1992:10).

Bevans (1992:12) also reminds us of the theological underpinnings of a local theology in the idea of the incarnation, as well as the affirmation of the sacramental nature of theology (where all of life is seen as a locus of God's presence and activity). The nature of divine revelation as present in believers' daily lives (1992:14), the catholicity of the church in championing the local, and the triune God's active, present and dynamic role in day-to-day realities, are all affirmed as important (1992:15).

The importance of contextualisation for theology is worked out in the pastoral cycle. Segundo (1976:9) describes this as the hermeneutical circle that begins with experienced reality - a real context. When discussing contextualisation, Bosch (1991:425) also refers to this dialectical relationship between theory and practice that has its roots in praxis, or experience.

However, Bosch (1991:427-428) cautions contextual theologians about viewing God as totally wrapped up in the historical process. Further dangers involve uncritical celebration of a variety of often exclusive theologies, which can often lead to absolutism. When taking these concerns into account, one must not allow the contextual and local realties to determine the truth of theology. What we are affirming here though, is that a theology that is divorced from local realities remains irrelevant and subject to potential ideological captivity and foundationalist assumptions. To realise God's presence in history and to begin with local issues means that we can begin the process of dialogue from the correct starting point. However, for a theologian to be local, he or she must identify, participate and give voice to the experience of the local situation out of which his or her theology arises.

\section{EXPERIENCE AS SOURCE}

Many are aware of John Wesley's quadrilateral, in which he posits four sources that need to be taken into account when conducting theological reflection. They are: experience, tradition, reason and Scripture. Grenz (1994:15) cautions against the use of experience as a source for theology and sees it rather as the medium through which sources are received. However, he does argue that just because it is not normative for theology, does not make it irrelevant 
(Grenz 1994:17). In his elevation of culture as a source of theology, he might in fact be engaging with people's experience as a source, without knowing it. Again, we do not argue that one's experience is true, but again affirm that experience must be our starting point. James Cone (1990:23) is one who argues that black experience should be one's starting point when doing local and contextual theology. Chung Hyun Kyung, who attempts to delineate what an Asian women's theology should look like, elevates Asian women's experience as a starting point when beginning theological reflection. A quote from her best illustrates what we mean by experience as the starting point for theological reflection (Hyun 1990:22):

\begin{abstract}
Asian women's theology was born out of Asian women's tears and sighs and from their burning desire for liberation and wholeness. It is neither the logical consequence of academic debate of the university nor the pastoral conclusion of the institutional church. Asian women's theology has emerged from Asian women's cries and screams, from the extreme suffering of their everyday lives. They have shouted from pain when their own and their children's bodies collapsed from starvation, rape, and battering. Theological reflection has emerged as a response to women's suffering.
\end{abstract}

Someone's experience, or one's own personal experience, gives birth to the pastoral concern that begins the pastoral cycle for Practical Theology. Of necessity, this raises the question as to the location of the theologian or "theological reflector." Can Practical Theology be done without some form of engagement by the one doing the theological reflecting? Clodovis Boff gives three ways in which a theologian can be engaged with the theological process. Before doing this, however, he makes some presuppositional comments around the idea of "engagement" that must be taken into account when discussing experience as a starting point for theological reflection.

The truth is that one need not begin theological reflection from experience or the local to be "engaged" (Boff 1987:160). Indeed, by nature, everyone is engaged to some extent and all theologians "do theology in and from some determinate social locus" (1987:159). An engaged theology can be "traditionalist" or "progressive" and its content is usually defined according to one's ideological position (1987:161). There are also important distinctions and overlaps between practical engagement and theoretical engagement (1987:168). The three types of engagement that Boff lists with regard to local and experiential realities are as follows.

1. The specific contribution model. Here, engagement is done at a theoretical level where intellectual positions are taken on behalf of a group or individual's local experience (Boff 1987:168). However, pure theory can only have practical implications through practical participation. By this, Boff (1987:169) means that one ought to have certain channels and opportunities to engage with the experience and local reality that one seeks to represent.

2. The alternating moments model. This might be seen as a sort of dualism - the theoretical and practical moments coincide. In one moment, the theologian is reflecting; yet, in the other moment, he is participating in the actual lived experience of a group of which the reflection forms part (Boff 1987:170). It is not so much a dualism as it is, rather, a series of alternating movements of the one who is engaging (1987:170).

3. The incarnational model. Here, one does not so much identify with a specific group, and participate in that lived experience, as much as one actually is joined in the "general life condition and lot of the group in question" (Boff 1987:170). In certain circumstances, this sort of identification might make theological reflection difficult in terms of materials at one's disposal (1987:171). 
These three models provide a picture of what sort of engagement is necessary for theological reflection that is local and takes into account experience as a starting point for theology. It is important that we realise that Practical Theology does not take place in a vacuum, and is somehow privy to some sort of theological and experiential neutrality. In what has been discussed, it might appear that a position has been taken that states that, unless someone is part of, or sympathetic to, a specific local context and experiential dynamic, they cannot do good theology. It might appear that, unless someone is bound within a specific pastoral concern, they are really unable to be truly concerned. Bevans (2002:21) says the following in this regard:

A person can in several significant but limited ways contribute to the contextualisation of theology in a context that is not his or her own. But when a person does this, he or she must approach the host culture with both humility and honesty. He or she must have humility because he or she will always be on the margins of the society in which he or she has chosen to work.

What Bevans says of cultures applies equally to any specific pastoral concern that Practical Theology uses as a starting point. For this reason, Hendriks (2004:26) places such emphasis on the fact that the laity and believers ought to be "producers of theology." For this reason, the best form of theological reflection on the church and her practical engagement flows from those who are actually engaged in that church, the contextual dynamics, and lived experience of that community.

Here, the argument has been for the local nature of Practical Theology as it best illustrates a post-foundationalist approach to theological reflection. It is a Practical Theology that places high value on experience as a starting point and source for theological reflection, as against and applied theology based on foundationalist assumptions. It is a Practical Theology that seeks to take the local seriously by identifying or participating with the lived experience of a particular group or individual. At this point, it would be unwise not to bring the global nature of Practical Theology into the discussions. The local situation with the lived experience of that local group has, at the same time, a global influence to it. A simple analysis and understanding of the local might provide a skewed picture of what is happening, and even the possibility to bring about change might be thwarted. Financial markets and policies on different continents can have a vast and long lasting impact on the local situation in which one finds oneself. Ideological currents and economic instability can radically alter one's lived experience. In taking into account the local nature of theology, we must also take into account the global. This tension of analysis the researcher has chosen to call the "glocal" (local and global) nature of Practical Theology and theological reflection. With specific reference to Africa, Hendriks (2004:27) speaks of the global dimension of Practical Theology: "In doing theology in Africa, we must be realistic about our situation in Africa. Theology should study the global, social, economic, political megatrends and how they influence our continent. What are the national and local realities with which we should deal?"

\section{THE GLOBAL NATURE OF PRACTICAL THEOLOGY}

We have been focusing on Practical Theology's local nature, as well as the importance of experience as a starting point for theological reflection. Any analysis of one's local situation and its contextual realities must take into account global dynamics that are brought to bear upon one's situation. Bonino (1975:5) shows how Latin America has been at the mercy of outside factors from the very beginning of colonial times. The lust for wealth and power in Spain saw 
the local people's culture destroyed and desecrated. Even later when independence was gained from Spain, the ruling classes connived with foreign banks, countries and institutions to bring about new levels of exploitation and an era of neo-colonialism (1975:16). Global factors, of which one has no control, affected people's local context and helped to define their experience and identity. Bonino (1975:31) shows how the capitalist form of production has had adverse effects on the dependent countries. Bonino was writing in the 1970s and could not have foreseen to what extent technology would add to the unfettered march of capitalism. This, certainly, is not an argument for any sort of communism or socialism, but merely points out what sociologists, such as Manuel Castells, have been showing us.

Castells (2004:1) points out that the world, in which we live, has become globalised to the extent that our whole social landscape has changed.

Our world, and our lives, are being shaped by the conflicting trends of globalization and identity. The information technology revolution, and the restructuring of capitalism, have induced a new form of society, the network society.

Individuals, groups and regions that do not service the goals of this network society are simply ignored or "switched off" (Castells 2004:3). The intense and changing global world in which we live has resulted in massive insecurity for many.

In a world of global flows of wealth, power, and images, the search for identity, collective and individual, ascribed or constructed, becomes the fundamental source of social meaning ... identity is becoming the main, and sometimes the only, source of meaning since in an historical period characterized by widespread destructuring of organisations, delegitimation of institutions, fading away of major social movements, and ephemeral cultural expressions (2004:3).

Globalisation is a fact. The reaction against globalisation, in the rise of national (not state) identities, is testament to this. Therefore, it is only logical that a Practical Theology that has experience as a starting point, and one seeking to be local, must at the same time give due attention to global factors. It must be a glocal Practical Theology. It must ask questions as to what economic, cultural, political and social realities in the rest of the world are impacting on one's local reality. Segundo says ((1976), this is part of the suspicion toward ideological superstructures arising out of one's experience that ought to be challenged. This could be worked out in a myriad of ways. The local clothing industry in the Cape could collapse due to the rising power of China. Inflation, with its impact on local households and their ability to feed themselves, has its roots in conflicts in the Middle East, monopolies and speculators.

Practical Theology certainly has seen a move to the local in the last quarter of the $20^{\text {th }}$ century, as against abstract applied theology based on foundationalist assumptions with its quest for certainty. However, this return to the local must take into account global factors that impinge on people's identities and experience, noting the "increasingly interconnected character of all human, political, economic, and social life on earth" (Hendriks 2004:27).

But, how do we go about understanding this glocal context? How do we take into account experience as a starting point, while trying to get to grips with local and global factors that influence that experience? What is called for is some form of social analysis.

\section{SOCIAL ANALYSIS}


Don Browning's fundamental Practical Theology argues for four movements within Practical Theology. Here, the first movement concerns us which is, what he calls, "descriptive theology." Descriptive theology is linked directly to what has just been discussed regarding the glocal nature of Practical Theology with its starting point in experience. Browning (1991:47) describes it as follows:

Its task is more important than its name. It is to describe the contemporary theory-laden practices that give rise to the practical questions that generate all theological reflection. To some extent, this first movement is horizon analysis; it attempts to analyse the horizon of cultural and religious meanings that surround our religious and secular practices.

This desire to begin with descriptive theology, by necessity, implies the importance of social analysis. The human sciences are directly linked to descriptive theology in their role of determining the concrete reality that will, at a later point, be brought into dialogue with the Christian sources (Browning 1991:92-93).

Gerben Heitink (1999:221) takes into account the anthropological shift in theology, characterized by the empirical shift in Practical Theology since the 1960s (1999:220). None would doubt that there has been this empirical shift in Practical Theology, but we do need some perspective on this issue which I think Heimbrock (2011:155) provides us with:

... the empirical interest within Theology is neither an invention nor the sole property of Practical Theology. "Empirical Theology" as an explicit and programmatic formula has been labelled in the beginning of the 20th century, in remarkable theological efforts on both sides of the Atlantic. And this happened long before Practical Theology got its present form.

Heitink (1999:221), like Browning, believes the empirical data, which the social sciences uncover, is of utmost importance for theological reflection. This leads him to "an empirically orientated Practical Theology, which opts for a point of departure in the actual experiences of people and the situation of church and society, and is characterized by a theorizing approach that attempts to do full justice to empirical data."

Clodovis Boff sets out to demonstrate the importance of social analysis and the role of the human sciences for theological reflection. Although his work focuses mainly on the role they offer with regard to political theology, the insights are still of real use. Like those already mentioned, he affirms that a theology orientated toward practice must take into account the sciences of the social. This becomes important in what Boff (1987:6) calls "a socio-analytic mediation." The importance of the use of the social sciences is not just to gain a correct understanding of a given situation, but to help theology to avoid the abstract speculation that endangers real change. Boff (1987:7) puts it graphically in the following manner:

The interfacing of theology with praxis through the medium of socio-analytic mediation has as its objective the safeguarding of theology from the empty "theorism" that, in certain circumstances, is a trait of academic cynicism that ignores the crying scandal of the starving and suffering multitudes of our world.

This must serve as a constant reminder that the use of the social sciences is not just for methodological integrity, but also has real people and their real situations as its focus. The social sciences, however, are not devoid of ideology with regard to both content and method. This will form an important part of our discussion later when the religious nature of the social sciences 
will be examined. At this point, we should note some of the obstacles that one encounters when discussing the importance of the social sciences. Boff mentions five, which we shall briefly discuss and acknowledge.

\subsection{Empiricism}

Here, the importance of social analysis is argued against on the basis that the issues are selfevident and the concerns are immediate. Lacking social analysis here can lead to multiple misunderstandings as to what is actually taking place (Boff 1987:21). Natural scientific knowledge must form the basis of theological cognition. Those who claim that the facts are self-evident, and that no non-theological disciplines are therefore needed, might simply get caught up in "certain current, ideological images that common sense forms of facts" (1987:22).

\subsection{Methodological purism}

Here, socio-analytical mediation is excluded on the basis that theology has its own proper status and has no need of other disciplines (Boff 1987:24). This does not take into account that Theology, by its very nature, has arisen out of social reality and is socially mediated. Boff (1987:25) rejects this option and argues that theology ought to assume that it takes the raw material of life into account and seeks to do so critically.

\subsection{Theologism}

In many ways, theologism is linked to methodological purism in the sense of claiming theology's unique and independent status. Here, theology believes it possesses within its storehouse, all the resources necessary to comment on any given situation - whether political or otherwise (Boff 1987:26). It has its roots in a view of the world that argues for the transcendent nature of truth and a deeply sceptical attitude to real life (1987:27). Boff argues against theologism believing that one must take into account the silent prerequisites that the social sciences afford us in understanding reality (1987:26).

\subsection{Semantic mix}

Here, the insights of the social sciences are not so much discarded as they are not integrated critically or properly (Boff 1987:28). On the one hand, the information is taken into the theological discourse without proper attention to its role. On the other hand, things that emerged from the analysis, which one cannot tolerate or accept, are replaced by more spiritual content. It seeks to collapse the tension into either corner instead of seeking to hold the insights of the social sciences in creative tension (1987:28).

\subsection{Bilingualism}

Bilingualism is related to that of semantic mix and it is quite difficult to distinguish between the two. Essentially, what happens here is that the social sciences and theology interact on the same "field," yet speak two different "languages." What happens in this scenario is that one of the different languages will seek to overcome the other and force it aside (Boff 1987:29).

\section{A WAY FORWARD?}

Boff (1987:30) believes that a healthy relationship and appropriation of the social sciences are possible despite these difficulties and objections. He believes that theology ought to understand that its formal object must be distinguished by its material object. In other words, what emerges from the social sciences is not theology in the proper sense of the word. He explains it in the 
The sciences of the social furnish theology only with that upon which to ply its practice. Thus what for the sciences of the social is a product, finding, or construct, will be taken up in the theological field as raw material, as something to be (re)worked by procedures proper to theologizing, in such wise as to issue in a specifically theological product, and one so characterized.

The importance of the social sciences for Practical Theology cannot be disputed, despite the objections, which we have just examined with Boff's help. Of course, there are dangers inherent in the use of the social sciences. Boff himself has called for theology as a theoretical discipline to be aware of, and shaped, according to its own grammar. The truth is that Practical Theology today has unanimously accepted the importance of the social sciences - and perhaps uncritically so. Yet, Browning (1991:89) argues that we might have done so uncritically without taking into account the ideological bent of the social sciences and, indeed, the researcher's situatedness.

\section{CONCLUSION}

We have noted that both liberal and conservative dimensions of theology have been influenced by foundationalist assumptions - both with regard to the quest for an unquestioned starting point, as well as the goal of achieving certainty in knowledge. This quest manifested itself within Practical Theology which became a form of applied theology. This led to little room for the local realities with their more relative dimensions.

It is apparent that with the wide adoption of the pastoral cycle within Practical Theology we have seen a move beyond foundationalism. Knowledge is never absolutely certain, and is in many ways relative, as it emerges from different contexts and situations. Here experience is emphasized as a starting point (not foundation) which is then engaged with theoretically and then again returns to that context/practice. This process is continued as new knowledge and information emerges from local and global factors. In this way we might argue that Practical Theology has indeed moved on from its foundationalist assumptions.

\section{BIBLIOGRAPHY}

Ballard, P. \& Pritchard, J. 2006. Practical Theology in action: Christian thinking in the service of church and society. SPCK. Great Britain.

Baranov, D. 2005. Conceptial foundations of Social research methods. Paradigm. Boulder.

Bevans, S.B. 2002. Models of contextual theology. Orbis. Maryknoll.

Boff, C. 1987. Theology and praxis: Epistemological foundations. Orbis. Maryknoll.

Bonino, J.M. 1975. Revolutionary theology comes of age. SPCK. London.

Bosch, D.J. 1991. Transforming mission: Paradigm shifts in theology of mission. Orbis. Maryknoll.

Browning, D. 1991. A fundamental and Practical Theology: Descriptive and strategic proposals. Fortress. Minneapolis.

Castells, M. 2004. The power of identity. The information age: economy, society and culture, volume II. 2nd ed. Blackwell. Oxford.

Chopp, R.B. 1995. 'Educational Process, Feminist Practice.' Christian Century, Vol 112/4, pp. 111-116.

Cochrane, J.R, de Gruchy, J.W \& Petersen, R. 1991. In word and Deed: towards a Practical Theology for Social Transformation. Cluster Publications. Pietermaritzburg.

Cone, J.H. 1990. A Black Theology of Liberation. Orbis. Maryknoll.

Cronshaw, D. 2011. 'Re-invisioning theological education, mission and the local church.' Mission Studies Vol 28:1, pp 91-115. 
De Kock, W. 2009. 'Open Seminary' Retrieved 14 November, 2011. http://www.openseminary.com/

De Kock, W. 2011. 'Open Seminary at Tabor. Master of Arts in Church Practice' Retrieved 14 November, 2011. http://www.tabor.vic.edu.au/files/publications/course-promo/2009-MACP-information-booklet. pdf

Graham, E., Walton, H. \& Ward, F. 2005. Theological reflection: Methods. SCM. London.

Grenz, S.J. 1994. Theology for the community of God. Eerdmans. Grand Rapids.

Grenz, S.J \& Franke, J.R. 2001. Beyond foundationalism: Shaping theology in a post-modern context. Westminster. Louisville.

Heimbrock, H.G. 2011. ' Practical Theology as Empirical Theology.' International Journal for Practical Theology, vol.14, pp. 153-170

Heitink, G. 1999. Practical Theology: History, theory, domains. Eerdmans. Grand Rapids.

Hendriks, H.J. 2004. Studying congregations in Africa. Lux Verbi. Wellington.

Hyun Kyung, C. 1990. Struggle to be the sun again: Introducing Asian women's theology. SCM. London.

Kim, H.S. (2007) The Hermeneutical-Praxis Paradigm and Practical Theology. Religious education, Vol.102, No.4, pp.419-436.

Kretzschmar, L. 1994. 'Ethics in a Theological Context' in: Villa-Vicencio, C \& De Gruchy, J, Theology and Praxis. Doing Ethics in Context: South African Perspectives. Orbis. Maryknoll.

Kung, H. 1978. Does God exist? Collins. London.

Macallan, B. A post-foundationalist approach towards doing Practical Theology: a critical comparison of paradigms. Doctoral dissertation, Stellenbosch University. http://scholar.sun.ac.za/ handle/10019.1/20127

Muller, J. 2009. 'Transversal rationality as a practical way of doing interdisciplinary work, with HIV and Aids...' Paper presented at the Seventh International Conferenc1e on New Directions in the Humanities, 2-5 June 2009, Bejing, China.

Poling, J. 2009. Toward a Constructive Practical Theology: A Process-Relational Perspective, in: International Journal of Practical Theology, vol. 13, pp. $199-216$.

Schrag, C.O. 1992. The resources of rationality: A response to the postmodern challenge. Indiana University Press.

Segundo, S.J. 1976. The liberation of theology. Orbis. Maryknoll.

Thiel, J.E. 1994. Nonfoundationalism: Guides to theological enquiry. Fortress. Minneapolis.

Van Huyssteen, Wentzel. 1997. Essays in postfoundationalist Theology. Eerdmans. Grand Rapids.

Whitehead, J.D. \& Whitehead, E.E. 1995. Method in ministry: Theological reflection and Christian ministry. Sheed \& Ward. Lanham.

\section{KEY WORDS}

Practical Theology

Foundationalism

Pastoral Cycle

Post-foundationalism 